\title{
Getting ahead of the game
}

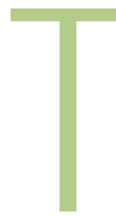

here is a saying that the only reliable source of knowledge is experience. Certainly, good judgment most often comes from experience. But most experience is gained as a result of bad judgment. It is even possible, given enough money, to learn how to run a life sciences biotechnology company properly by making lots of mistakes. But if you really want to build an empire, empiricism is not necessarily the best way.

The business of biotechnology is still very young and its history is largely an oral one. As a result, many entrepreneurs repeat the mistakes of their predecessors. Even in these days of professional management, many who start commercial biotechnology enterprises are scientists with no background or familiarity with thelanguage and habits of thebusiness world. What's more, biotechnology operates in an environment whose only constancy is change. $M$ arkets in healthcare and agriculture evolve rapidly; tradeglobalizes and digitizes; knowledgegrows and stuns; technology transforms. Consequently, biotech business models are mostly unproven (and, in any case, timemay changetheir ability to succeed). It is still difficult to makea biotechnology company profitable- only around 75 profitable public biotechnology companies exist.

Themain purpose of thissupplement isto provide guidance, thereby, perhaps, marginally increasing the chances of success, for those interested in starting or nurturing biotechnology ventures. It aimsto allow aspiring bioentrepreneurs to peek at the experiences and gain from the wisdom of those who have either learnt the hard way themselves or spent their time observing others doing so.

We have grouped articlestogether in three sections: Starting Out, Growing Pains, and M aturity. Thefirst section provides advice for budding bioentrepreneurs seeking to transform new scientific discoveries into viable commercial opportunities. It includesarticles on how to focus business plans to achieve sustainable growth with changing circumstances, the essential stepsin protecting intellectual property, and advice on the acquisition of business and managerial acumen. The section also provides profiles of eight new ventures selected on the basis of the promiseand novelty of their technologies.

The second section (Growing Pains) deals with some of the issues that face a biotechnology company considering a public list- ing- attracting and retaining personnel, forging strong relationships with corporate partners, managing risk, and preparing for clinical development. M any companies at this stage now face institutional investors who appear to beresistant to providing funds for biotechnology companies with low valuations and a lack of liquidity.

Companies that are publicly listed and have products nearing approval are the focus of the last section (M aturity). These enterprises face the challenge of turning their bottom-lines black. Issues that are covered here include public relations strategies, cultural and logistical problems in bioinformatics, knowledge management, and the potential problem of patent expiry.

Bioentrepreneurs arerare, flexible, and knowledgeable individuals driven (in part) by the enormous challenge of making a successful biotechnology venture. Some may even bealtruists, aiming to nurture the promise of basic discoveries to into worldimproving products. Steering a company from early birth, through adolescence, to adulthood and maturity requires a range of skills, many more than arein the possession of any one person.

Bioentrepreneurship is a collegiate enterprise that in a single company may need several executive generations. The class of ' 01 may find seed funding, secure a basic intellectual property position, attract capital from venturefirms, and hire the right balance of personnel (all whilekeeping cash burn under control) but it will be the class of ' 06 which has to target the right customers, adapt the business plan to meet new competitive threats, getting the company's message "out there" and jump through the appropriate public financing window. And it may bethe class of ' 11 that gets all the plaudits (but only if they have managed to shepherd products through the clinic and regulatory bodies, and acquiremanufacturing capacity).

This supplement is intended to provide a readable guide that outlines some practical tips for getting a biotechnology venture off the ground or moving to the next stage of development. It is not a substitute for professional advice - after all, professional advice isn't free. But it might help a new generation of aspiring entrepreneurs to assimilate some of the hard lessons of the past. I thank the authors for providing their time and sharing their insights. 